\title{
Usaldus internetis - juurdepääs ja suhted uuritavatega
}

\section{Katrin Tiidenberg}

Teesid: Artikkel käsitleb seda, kuidas saavutada kvalitatiivses internetiuurimuses juurdepääs uurijat huvitavatele kogukondadele, ning mida teha soodsa uurimisõhkkonna loomiseks olukorras, kus uurija ja uuritav näost näkku ei kohtu. Andmete loomiseks ja kogumiseks ja nende kontekstitundlike tõlgenduste saavutamiseks on olulised uurija ja uuritava omavahelised usaldusväärsed suhted. Veebikeskkonnas mõjutavad suhtluse ja usalduse tekkimist ja toimimist nii võrgutehnoloogia üldised võimalused kui ka konkreetsete sotsiaalmeediaplatvormide tehnilised ja sotsiaalsed lubavused. Visuaalsete ja sotsiaalsete viidete vähesus ning anonüümne või pseudonüümne suhtlus ei takista iseenesest usalduslike uurimissuhete tekkimist, kuid nendega peab arvestama. Selle meetodite ja tehnoloogia kokkupuutekoha avamiseks toetub antud artikkel autori mitmeaastasele kogemusele enesepildistajate kogukonna uurimisel Tumblr.com keskkonnas. Artikkel kirjeldab, kuidas autor kasutas uuritava kogukonna suhtlusreegleid ning veebikeskkonna ja konkreetse platvormi lubavusi (affordance) kontakti saamiseks ja uurimissuhete ülesehitamiseks, ning analüüsib seda, kuidas toimib uuritud kogukonnas usaldus. Kokkuvõtvalt pakub artikkel lugejale rea küsimusi, millega arvestades on ka võrgutehnoloogiast vahendatud kvalitatiivses uurimuses võimalik saavutada usalduslikud uurijasuhted.

Märksõnad: digitaalne uurimus, internetiuurimus, juurdepääs väljale, suhted uuritavatega, usaldus 
Õnnestunud kvalitatiivne uurimus tähendab rikkalikke andmeid ja tihedaid kirjeldusi. Selle saavutamine eeldab sageli intensiivset kontakti uuritavate inimestega. See omakorda tähendab, et uurimuse edu sõltub suurel määral uurija suhtlusvõimekusest (Flick 1998, 55). Osaliselt või täielikult võrgutehnoloogiaist vahendatud uurimuse puhul on suhtluse ja suhete loomine, haldamine ja alalhoidmine paljude spetsialistide meelest keerulisem kui näost näkku uurimisolukorrad (Orgad 2005; Sanders 2005; James \& Busher 2009). Miks see nii on? Kas interneti ja veebisuhtluse tehnilised ja sotsiaalsed tunnused mõjutavad suhteid niivõrd olulisel määral?

Sellele küsimusele vastamiseks toob käesolev artikkel esmalt ära mõned klassikalised kvalitatiivses meetodikirjanduses antavad nõuanded uurimissuhete ja -atmosfääri loomiseks. Seejärel peatun sellel, kuidas võrgutehnoloogiate ja sotsiaalmeedia platvormide lubavused ja muud tunnused veebisuhtlust piiravad ja vormivad. Meetodite ja tehnoloogia ristumis- ja kokkupuutekoha lahtimõtestamiseks toetub artikkel minu uurimusele enesepildistajate ja blogijate kogukonnaga Tumblr.com keskkonnas. Leian, et selle kogukonna omavahelistest suhetest ning grupidünaamikast on ka uurimussuhete seisukohast nii mõndagi õppida.

\section{Juurdepääs ja õhustiku loomine kvalitatiivses uurimuses}

Paljud kvalitatiivseid meetodeid kasutavad sotsiaalteadlased usu$\mathrm{vad}$, et andmete kogumine ei ole neutraalne protsess. Andmeid ei "leita" ega talletata, vaid pigem luuakse uurija ja uuritava vahelises dialoogis. Käsitlen kvalitatiivset uurimust sotsioloogi ja kommunikatsiooniuurija perspektiivist. Usalduse ja uurimissuhete mõistmiseks keskendun intervjuu-uuringutele, mille puhul intervjuud (k.a fookusgrupid) on peamine või ainus andmekogumise viis; ning etnograafilistele uuringutele,${ }^{1}$ mis tähtsustavad (osalus)vaatlust, kuid hõlmavad alati paljusid erinevaid andmekogumisviise (osalus, vaatlus, intervjuud jms).

${ }^{1}$ Tom Boellstorff, Bonnie Nardi, Celia Pearce ja T. L. Taylor (2012) kirjutavad, et etnograafilise uurimuse eesmärgiks on "mõista ühiseid praktikaid, tähendusi, sotsiaalseid kontekste ning nendevahelisi seoseid" (lk 67) ning luua "konkreetsete kultuuride detailsed ja kontekstipõhised kirjeldused, mis peegeldavad kultuuri liikmete seisukohti" (lk 14). 
Kvalitatiivsete andmekogumismeetodite kasuks otsustatakse üldjuhul siis, kui uurimisküsimusele vastamiseks on vaja võimalikult põhjalike andmete kontekstitundlikke tõlgendusi. Selliste andmete ja tõlgenduste jaoks on vaja uuritavale nähtusele lähedale pääseda, mis üldjuhul eeldab hea kontakti saavutamist huvitava grupi, selle võtmeliikmete või neid hästi tundvate indiviididega (Hesse-Bieber \& Leavy 2011, 201). Seejuures on uurimisolukordades - nii nagu tavaeluski - suhteid ja nendega kaasnevaid tundeid mitmesuguseid. Täheldatud on kõike ihast tülgastuseni ja võimust abituseni (Kendall 2009).

Kuna suhted on kvalitatiivse uurimuse eesmärkide saavutamiseks olulised, kirjutatakse metoodikatekstides palju konkreetsetest suhtlustaktikatest. Intervjueerimisõpetustes räägitakse õhustikuloomest (ingl building rapport), mille peamine eesmärk on "tekitada intervjueeritavas turvalisuse, mugavuse ja väärtustatuse tunne" (Hesse-Bieber \& Leavy 2011, 105). Selleks soovitatakse näiteks enne intervjuu alustamist igapäevastel teemadel vestelda, kasutada erinevaid aktiivse kuulamise taktikaid, nagu silmside ja noogutamine; ning vältida hukkamõistvana näimist (samas).

Etnograafiliste meetodite puhul räägitakse pigem juurdepääsust (ingl access), mida Giampetro Gobo $(2008,122)$ nimetab lausa etnograafilise uurimuse keerukaimaks osaks. Gobo (2008) järgi on juurdepääs kaheetapiline - esimene puudutab juurdepääsu saamist väljale (ingl getting in) ja teine sotsiaalset juurdepääsu (ingl getting on). Mõlemad eeldavad koostööalteid osalisi, kogukonnalt või väravahoidjalt (ingl gatekeeper) uurimusele heakskiidu saamist, ning kogukonna usalduse võitmist (samas).

Juurdepääsu ja soodsa uurimisõhustiku loomist käsitleb niisiis iga kvalitatiivsete meetodite õpik. Juurdepääsu hõlbustab see, kui grupis kedagi tunda, ent seejuures on oluline vältida olukorda, kus uurimisprojekti eestkostjaks saab ebapopulaarne grupiliige (Tracy 2013). Juurdepääsu ja suhtlust soosib ka see, kui uurija ja uuritav on sarnase staatuse (nt vanus, sugu, rass) ja välimusega (nt riietus) (Hesse-Bieber \& Leavy 2011). Ehkki sellised soovitused on kahtlemata asjalikud, tuleks meeles pidada, et juurdepääs ja suhtlusõhkkond ei ole mehhaaniliselt sooritatav ülesanne. Pigem on tegemist elava ja elulise protsessiga, mis on igas suhtlusolukorras osalejate läbirääkimiste tulemus (Goffman 1956). 


\section{Veebipõhise suhtluse iseärasused}

Varajased internetiuurimused keskendusid sageli sellele, mis vahendatud suhtluses kaduma läheb või puudu on. Kuna veebis valitses aastaid peamiselt tekstipõhine, sageli asünkroonne ${ }^{2}$ eneseväljendus, keskenduti keeleüleste viidete (ingl paralinguistic cues) $)^{3}$ vähesusele. Eeldati, et keeleüleste viidete puudumise tulemiks on lamedam, formaalsem, või ülesandesooritusele keskendunud (Joinson 2005, 22); emotsioonitu või ülemäära negatiivne suhtlus (Kiesler et al. 1984; Sproull \& Kiesler 1991). Ajalugu on need väited ümber lükanud. Inimesed kasutavad keeleüleste viidete puudumise kompenseerimiseks akronüüme, kirjavahemärke, emotikone, GIFe ja emojisid.

John Suler (2004) leiab, et veebisuhtluse puhul on inimesed pigem avameelsemad, ta pakkus välja veebivabameelsuse mõiste (ingl online disinhibition effect), mis tähendab, et teatud isikuomadused ja veebisuhtluse tunnused (nt anonüümsus, ajalõtkuga suhtlus, nähtamatusetunne) loovad kombineerituna olukorra, kus inimesed hoiavad end vähem tagasi. See võib avalduda nii positiivses (abistamine, kaastunne) kui ka negatiivses (kiusamine, häbistamine) käitumises.

Ühelt poolt kehtib ka veebis endiselt Goffmani (1956) tähelepanek, et igale emotsionaalselt intelligentsele inimesele on omane püüd esitleda end nii, et temast jääks positiivne mulje. Seda tõlgendatakse sageli küüniliselt, kahtlustades, et kõik see, mida inimesed enda kohta veebis ütlevad, on liialdus või lausvale. Samas on paljud uuringud näidanud (Baym 2000; Henderson \& Gildig 2004; Ellison \& Heino \& Gibbs 2006; Cover 2012; Hall \& Pennington 2012; Baym $2015 \mathrm{kaudu}$ ), et ehkki eneseesitlus on veebis valikuline ja osaline, püüdlevad inimesed enamasti iseendast tõese ${ }^{4}$ kuvandi loomise poo-

${ }^{2}$ Suhtluspartnerid ei osale suhtlussituatsioonis samaaegselt.

${ }^{3}$ Keeleülesed viited on näiteks hääletoon, žestid, näoilmed. Osade autorite kõnepruugis nimetatakse neid ka sotsiaalseteks viideteks (ingl social cues). Suhtluspartnerid käsitavad keeleüleseid või sotsiaalseid viiteid lisavihjete või informatsioonina öeldu tõlgendamiseks.

${ }^{4}$ Võrdlused autentse ja võltsi, esitlusliku ja "päris" mina vahel kaotavad tähenduse, kui hakkame autentsust defineerima. Kui määratleme autentseks ainult vahendamata ligipääsu indiviidi "tõesele olemusele", juhib veebisuhtluse vahendatus ja ajalõtk kõigest tähelepanu vanale poststrukturalistlikule väitele, et absoluutne autentsus ei olegi võimalik. Kogu eneseesitlus on üks suur etendus, kõiki meie eneseesitlusi vahendab keel ning autentsus on seega sotsiaalne konstruktsioon, meie suhtluse tulemus, mitte mingi olemuslik nähtus (Smith \& Watson 2014). 
le. Piisavalt tõelähedase eneseesitluse tulemuseks on sõprussuhted, lähedusetunne, võimalus paluda ja saada sotsiaalset ja emotsionaalset tuge. See tähendab, et vassimiseks ei ole lihtsalt põhjust. Teisalt suunab konkreetsete sotsiaalmeedia platvormide ülesehitus märkimisväärselt seda, kuidas me saame ja soovime ennast esitleda ja seal suhelda. Piiratud sotsiaalsete viidete kontekstis mängivad näiteks profiilid olulist rolli selles, kas, kuidas ja mis teemadel võõrad inimesed soovivad meiega suhelda. Seega piirab näiteks Facebooki ettemääratud küsimuste ja valikvastustega profiiliankeet märkimisväärselt seda, milline mulje meist potentsiaalsetele suhtluspartneritele jääb.

Siinkohal ongi mõistlik tuua sisse lubavuste ja piirangute mõisted. Lubavused koos inimeste soovide, vajaduste ja veendumustega määravad selle, kas, kuidas ja mille jaoks teatud tehnoloogiat kasutatakse. Piirangud ${ }^{5}$ on aga tunnused, mis muudavad teatud kasutamisviisid võimatuks või keeruliseks (Morrison 2014). Psühholoogiast (Gibson 1977) ja kasutajakogemuse ning disaini valdkonnast (Norman (1988 [1990]) pärinev lubavuste teooria käsitleb lubavusi inimese poolt tajutud tegutsemisvõimalikkustena. Selle mõistestiku abil saame analüüsida, mida konkreetsel platvormil või konkreetse rakendusega teha saab, millised tegevused tunduvad tänu kasutajaliidesele ${ }^{6}$ ja disainile lihtsad ja mõistlikud, milliste tegevuste sooritamiseks vajalikud nupud ja viited on aga sootuks ära peidetud.

danah boyd ${ }^{7}$ (2010) on pakkunud ühe rohkelt tsiteeritud määratluse sotsiaalmeedia üldistest lubavustest. Neid on neli: meie öeldu, kuvatu ja esitletu automaatsele salvestamisele ja arhiveerimisele viitav jäävuselubavus, bittidest koosneva sisu lihtsale duplitseerimisele viitav kopeeritavuse lubavus, sisu ülinähtavaks saamise potentsiaalile viitav skaleeritavuse lubavus, ning sotsiaalmeediasisu otsingumootoritele ligipääsetavusele ja masinloetavusele viitav otsitavuse lubavus. Lisaks on konkreetsetel keskkondadel või platvormidel spetsiifilisemat laadi lubavused, piirangud ja tunnused. Facebook surub peale nimelist, ühtainsat kontot ja eeldab osalemiseks profiili täitmist; Instagrami saab postitada ainult

\footnotetext{
${ }^{5} \mathrm{Nt}$ nukk, mille pea on suurem kui väikelapse suu, või kannmikser, mis ei käivitu, kui kaas peal ei ole.

6 S.o osa tarkvararakendusest, mida kasutaja näeb ja millega suhtleb, ühenduslüli kasutaja ja arvutiprogrammi vahel https://et.wikipedia.org/ wiki/Kasutajaliides.

${ }^{7}$ Artiklis järgitakse selle autori soovi kirjutada oma nimi väikeste algustähtedega. Vt www.danah.org/name.html.
} 
nutiseadmest; Snapchatis kaob foto pärast kümmet sekundit nii saatja kui ka saaja telefonist. Viimaks on erinevatel gruppidel ja kogukondadel ka konkreetsed, eelnevast vaid osaliselt sõltuvad kultuurinormid. Need kõik mõjutavad seda, kuidas inimesed saavad ja tahavad internetis suhelda, millised on need suhted (pika-, või lühiajalised, intiimsed või pealispindsed, leebed või agressiivsed) ning kuidas neid suhteid iseendale ja teistele kirjeldatakse.

\section{Kvalitatiivne uurimus veebis}

Internet võib olla uurimuse läbiviimse tööriist, uurimuse asukoht ja uuritav nähtus (Markham 2004, 95). Nancy Baym (2009, 179) soovitab hea kvalitatiivse internetiuurimuse puhul meeles pidada, et kvaliteedi tagab:

- $\quad$ andmete ja teooria integreeritud kasutamine,

- rangelt hoolas (ingl rigorous) andmekogumine ja analüüs,

- ja mitmete andmekogumisstrateegiate kombineerimine, mis:

1) arvestab osalejate vaatenurgaga,

2) läheneb uurimisprotsessile sisekaemuslikult,

3) ning on tähelepanelik selle suhtes, kuidas internet uurimuses osalejate igapäevaellu põimunud on.

Ta täiendab ja täpsustab seda nimekirja, mainides, et lisaks on hea internetiuurimus ajalooteadlik; kindla fookuse ja praktilise panusega; kasutab selget ja veenvat retoorikat; ning selgitab, mis uute tehnoloogiatega kaasneb ning kuidas uusi tehnoloogiaid käsitlev uurimus teiste elu- ja uurimisvaldkondadega seostub (Baym 2009). Väidan, et need punktid ei ole internetiuurimusele spetsiifilised, vaid on iga hea kvalitatiivse uurimuse tunnuseks.

Täna on kvalitatiivsete andmete kogumine ja loomine internetis / interneti kohta mitmekülgne ja multidistsiplinaarne. Enamikus kvalitatiivsete meetodite käsiraamatuis kirjutatakse intervjuudest, fookusgruppidest, vaatlusest ning tekstide, visuaalide ja audiosisu kogumisest (vt nt Uwe Flicki toimetatud SAGE Handbook of Qualitative Data collection 2017). Kõiki neid viiakse regulaarselt läbi veebis. Mida võrgustatum ühiskond, seda selgem, et inimeste igapäevaelu ei eristu teravalt online ja offline kogemusteks, mistõttu ei ole see 
vahetegemine ka metodoloogiliselt asjalik (vt Orgad 2009; Bakardjieva 2009; Gajjala 2009). Pigem on mõistlik keskenduda sellele, millised internetipõhised pinged uurimuse erinevates etappides esile kerkivad (Markham 2006). Antud peatüki kontekstis tähendab see keskendumist sellele, kuidas veebi ja sotsiaalmeedia lubavused ja piirangud just õhustiku loomise ja juurdepääsu saamisega seotud on.

\section{Juurdepääs ja õhustiku loomine veebis - näide enesepildistajate kogukonnast}

2011. aastal alustasin andmete kogumist oma doktoriväitekirja jaoks. Uurisin seksuaalselt eksplitsiitseid (edaspidi NSFW ${ }^{8}$ ) blogisid pidavate ja iseendast seksikaid selfisid postitavate inimeste kogukonda Tumblr.com ${ }^{9}$ nimelises keskkonnas, et mõista seda, kuidas on seotud võrgustatud tehnoloogia, kultuurilised praktikad ja inimeste mina-identiteet.

Tumblr on sotsiaalmeediaplatvorm, mille keskmes ei ole profiilid, vaid eri tüüpi sisuga blogid (fänniblogidest loovisikute portfoolioteni, isiklikest päevikutest kuulsuste päevaraamatuteni, erootilisest sisust kassipiltide ja ühiskondliku aktivismini). Lubavuste perspektiivist on Tumblri puhul oluline see, et kasutajatele ei suruta peale nimelist kontot, ei piirata blogide arvu inimese kohta, ning platvormi sisupoliitika on suhteliselt leebe. See tähendab, et erinevalt enamikust ülejäänud suurematest sotsiaalmeediaplatvormidest (Facebook, Instagram) ei tsenseeri ega keela Tumblr NSFW sisu postitamist. (2017. aasta suvel omandas USA korporatsioon Veriszon Tumblrit omava Yahoo ettevõtte ning sellege on kaasnenud teatud muutused sisuhalduspoliitikates, nii et see võib olla muutumas.) Nii on Tumblris tavalise, igapäevase või kunstipärase sisuga alati koos eksisteerinud n-ö 18+ sisu. Tumblris blogimiseks on vaja luua kasutajakonto, misjärel inimene saab pilte, videosid, audiot

${ }^{8}$ NSFW on internetidiskursuses levinud akronüüm (Not Safe For Work), millega veebikasutajad tähistavad seksuaalselt eksplitsiitset sisu.

9 Tumblr on 2007. aastal lansseeritud visuaalne blogimisplatvorm, kus oli 2017. aasta 1. jaanuari seisuga 329,3 miljonit blogi, 143,8 miljardit postitust (tumblr.com/about) ning 794 miljonit aktiivset kuukasutajat (Statista 2018). 
ja teksti postitada, taaspostitada ${ }^{10}$ ning valitud blogisid jälgida ${ }^{11}$, nende postitustele poolehoiutähiseid jätta, sisu kommenteerida ning blogiomanikega erinevaid suhtlusvahendeid (fännikiri, anonüümne või nimeline kiri, sünkroonne vestlus) kasutades suhelda.

Kuna mind huvitas selfiharjumuste, neile omistatud tähenduste, ja tehnoloogia tunnuste ning tõlgenduste omavaheline dünaamika, lähenesin uurimusele kvalitatiivselt, kasutades etnograafilisi meetodeid. Analüüsitav materjal koosnes osalusvaatluse märkmetest, intervjuudest, grupiintervjuudest ning blogiväljavõtetest ja selfidest.

Internetiuurimuse puhul on üheks suurimaks väljakutseks välja ja kogukonna ${ }^{12}$ määratlemine. Traditsioonilises antropoloogilises ja etnograafilises uurimuses on väli sageli asukohapõhine - selle piirideks on saar, küla või hõim. Mina lähenesin uurimisvälja piiritlemisele diskursusiivselt (Markham 2005). See tähendab, et nii uurimisküsimuse kui välja määratlemiseks oli vajalik esialgne (u pool aastat) osalusvaatlus, mille tulemusena olin teksti ja piltide põhjal võimeline määratlema laiemat NSFW välja, millel osales mitmeid erinevaid, osaliselt kattuvaid kogukondi. Neid liitis elu-, või blogimisstiil, ning sotsiaalne võrgustik, ehk see, millised blogijad üksteise sisust teadlikud olid ja kui tihedalt omavahel suhtlesid. Minu uurimisküsimus suunas mind isiklikke blogisid pidavate, selfisid postitavate NSFW blogijate kogukonna juurde. Kõik selle kirjelduse elemendid on olulised - NSFW väli on suur ja lai, isiklikke NSFW blogisid eristab ülejäänuist see, et nad postitavad mõtteid, unistusi ja ärevusi. Samuti leidub isiklikke NSFW blogisid, mille

10 Tumblri tähelepanuväärseim tehniline tunnus on taaspostitamise nupp (ingl reblog), mis võimaldab ühel kasutajal teise kasutaja sisu vaid ühe näpuliigutuse abil iseenda blogisse postitada. Selline lihtne sisujagamine on praegu sotsiaalmeedias väga levinud ja Tumblrit võib pidada selle tehnilise lahenduse populariseerijaks.

11 Tumblri blogisid on võimalik lugeda ka ilma kasutajakontot loomata, kuid selle jaoks on vaja meeles pidada nende URL-aadressid või bloginimed. ${ }^{12}$ Kogukonna mõiste on sotsiaalteadustes keeruline ning selle debati lahtiseletamiseks ei ole käesolevas peatükis piisavalt ruumi. Pikemalt peatun sellel teemal oma raamatus "Ihu ja hingega Internetis. Kuidas mõista sotsiaalmeediat" (2017b). Käesolevas peatükis käsitlen uuritud blogijaid kogukonnana, kuna (a) nende suhtluses, grupidünaamikas ning praktikais on olulised need viis elementi (ühine koht, ühised tegevused ja tegutsemisviisid; sotsiaalne tugi; ühised enesemääratlused, inimestevahelised lähedased suhted), mida omistatakse (veebi)kogukondadele (Baym 2015, 84), ning (b) nad ise kasutavad seda mõistet. 
pidajad ei postita selfisid. Minu esmane valim oli $24^{13}$ maailma eri paigust pärit, inglise keeles blogivat inimest, kellega antud kogukond muidugi ei piirdu, kuid kelle kaasamine oli esmastest vaatlusandmetest lähtuv strateegiline otsus. Valisin nemad, kuna nii oli mul juurdepääs paljudele erinevatele Tumblr kasutamise kogemustele ja viisidele.

Kuid kuidas need 24 inimest ikkagi minu uuritavateks said? Mida ma tegin juurdepääsu saavutamiseks ja sobiva suhtlusõhustiku loomiseks kiivalt pseudonüümses, üldlevinud moraalinormide seisukohast kergelt hukkamõistetavas ${ }^{14}$ tegevuses osaleva kogukonnaga? Nalita James ja Hugh Busher (2009) kirjutavad, et veebipõhine suhtlus tundub inimestele vähem formaalne ja see lihtsustab eneseavamist ning soosib sooje uurimussuhteid. Lisaks on täheldatud, et vahendatud suhete puhul on teatav lähedus saavutatav kõigest mõne päevaga (Guimarães 2005). Samas ei tähenda see, et kõik internetisuhted oleksid automaatselt soojad ja lähedased. Intiimsuse eelduseks on vastastikune eneseavamine (Archer 1979). Seega võib veebipõhise kiirendatud läheduse põhjuseid otsida just neist veebisuhtluse lubavustest, mis teevad vastastikuse eneseavamise hõlpsamaks ja ahvatlevamaks. Üks tõenäoline põhjus on võimalus suhelda anonüümselt ja pseudonüümselt. Annette M. Markham (2004) kirjutab, et anonüümsus võimaldab käituda sotsiaalsetest normidest, moraalidest ja tavadest vähem kammitsetud moel, kuid Shani Orgad $(2005,55)$ leiab, et anonüümse veebisuhtluse puhul on keeleüleste viidete vähesuse tõttu suhtluspartneri hindamiseks vähem infot, ja seega raskem tundmatut võõrast usaldada. James ja Busher (2016) nendivad, et usaldusliku suhte tekkeks on oluline visuaalsete ja sotsiaalsete viidete puudumine kuidagi kompenseerida, mis eeldab uurijalt veel üht lisaoskust.

Anonüümsuse võimalust peetakse probleemiks ka seetõttu, et uurijal on oluline teada, kes on tema uuritavad (nende öeldu tõlgendamiseks ja oma uurimistulemuste usaldusväärsuse tõendamiseks kolleegidele) ning uuritavate turva- ja usaldustunne sõltub sageli sellest, kas nad teavad, kes on uurija. Sotsiaalmeedia keskkondades on aga nii uurijail kui ka osalejail tehniliselt lihtne hiilida (ingl lurk), mis tähendab, et nad pääsevad ligi kogu antud platvormil

${ }^{13}$ Aastate jooksul kaasasin nende inimeste partnereid või neile olulisi kogukonnaliikmeid, ning osalejate arv kasvas 32ni.

${ }^{14}$ Kõik minu uuritavad on n-ö "alasti internetis" (Ray 2007), rikkudes nii üldlevinud kultuurinorme, mis väidavad, et avalik alastus, eriti kaubastamata kujul, ei ole aktsepteeritav. 
või kanalis avalikult jagatavale sisule, ent ei jäta oma olemasolust teistele nähtavaid märke. Internetiuurija peab seega olema valmis leidma lahendusi autentsuse ja anonüümsuseprobleemile, või suutma endale ja kolleegidele rahuldaval moel põhjendada, miks see tema uurimisküsimuse seisukohast määrava tähtsusega ei ole. Chris Mann ja Fiona Stewart leidsid juba 2000. aastal, et anonüümsuse ja autentsuse vaheliste dialektiliste pingete lahendamine peaks olema ühteaegu pragmaatiline ja igas uurimissituatsioonis erinev.

Mina sisenesin väljale osalejablogi ja pseudonüümiga, mille vahendusel märkasin ja omandasin esmased postitamise ja teiste blogide sisuga suhtlemise oskused. Vaikimisi kultuurireegleid omandades märkasin n-ö suhtluseelsete tegevuste olulisust. Nende hulka kuulub teiste blogide järgijaks asumine, nende postitustele regulaarselt poolehoiutähiste jätmine, interaktiivsetes postitusmängudes ${ }^{15}$ osalemine, ning teatud aja möödudes ka humoorikas, avalik dialoog. ${ }^{16}$ Nii tekkisid mul välja piiride mõtestamisega paralleelselt mõned esialgsed platvormisisesed suhted blogijatega, kes tegelesid mind huvitavate asjadega ning näisid olevat seotud paljude teiste mind huvitavate inimestega. Siinkohal on oluline mainida, et need esmased suhted kvalifitseeruvad suhetena ehk vaid selle välja kontekstis. Sisuliselt tähendasid need, et kaks pseudonüümset blogi on vastastikku teadlikud teineteise olemasolust, laias plaanis kursis teineteise postitatava sisuga, ning see sisu ei ole kummalegi vastumeelne. Nende suhetega ei kaasnenud selles etapis peaaegu mingit privaatset vestlust, seega ei oleks ma neid enne välitöid nähtavasti osanudki suheteks pidada.

Nende esmaste kuude tulemusel oli mul võimalik määratleda blogijad, kes tänu oma blogile ning selle kogukondlikule positsioonile võiksid toimida nii väravahoidjatena kui ka intervjueeritavate lumepallivalimi alguspunktidena. Lisaks aitas algne osalusvaatlus mõista, et peale aktiivselt postitavate blogide on kogukonnas ka olulisi hiilijaid või privaatseid blogisid pidavaid inimesi, kelle kogemused tuleks uuringusse kaasata. Välja suhtlusdünaamikat imiteerides murendasin oma esmase juurdepääsu saavutamiseks sooritatavad

${ }^{15}$ Näiteks taaspostitavad paljud blogijad sama nimistu küsimustest, mille hulgast lugejad saavad numbri järgi valida need, millele just nemad vastust sooviksid, vastused on avalikud ja humoorikad.

${ }^{16}$ Tol ajal oli platvormi sõnumirakendus piiratum kui täna, ning kogukonnas oli kombeks saata naljakaid, poolehoidu avaldavaid küsimusi ja neile avalikult vastata, küsimused-vastused oli üks blogipostituse tüüp, sellega ei kaasnenud enamasti privaatset suhtlust ja sõnumivahetust. 
tegevused mikrokommunikatiivseteks sammudeks. Esmalt asusin ennast huvitavat blogi järgima-jälgima ning suhtlesin ülalnimetatud moel autoriga, tehes oma pseudonüümi mind huvitavale blogijale äratuntavaks. Kui olin valmis alustama esimeste intervjuudega, saatsin valitud blogijaile platvormi sõnumirakenduse vahendusel lühikese mitteformaalse sõnumi. See oli omamoodi riskantne, sest rakendus võimaldab küsimused ühe nupuvajutusega avaldada ja totakate või solvavate küsimuste sarkastiliste vastustega avaldamine oli kogukonnas sel ajal levinud komme. Just seetõttu oli oluline teha oma pseudonüüm potentsiaalsele uuritavale eelnevalt tuttavaks. Esimeses sõnumis mainisin, et tegelen uurimistööga, kuid ei pakkunud kogukonna privaatsusenormidega kooskõlaliselt veel enda nime, riiki ega ülikooli. Sellele järgnes lühike dialoog sõnumirakenduses ning siis pseudonüümsete meiliaadresside põhine kirjavahetus huvitatud osalistega. Mina alustasin selles etapis eneseavamisega, öeldes vestluskaaslasele oma pärisnime ja tutvustades uurimust. Lubasin, et pärisnime avaldamine ei ole osalemiseks vajalik, ent jätkamine eeldab pseudonüümset informeeritud nõusoleku andmist. Seejärel leppisin kokku esimesed intervjuud, mille lahutasin taas kaheks etapiks: asünkroonne meili-intervjuu ning reaalajas toimuv süvaintervjuu. Meili-intervjuu algas kolm päeva enne kokkulepitud sünkroonse intervjuu aega ning selle eesmärk oli teema sisse juhatada ja luua õhustik, mis võimaldaks kahel sisuliselt võõral inimesel vestelda tuhandete kilomeetrite tagant teineteisega pikalt ja põhjalikult väga isiklikel teemadel. Meili-intervjuud toimisid emotsionaalse ja suhtlusstilistilise timmimisvahendina, aidates nii minul kui ka vastajal ühist keelt leida. Minu silmis oli kõnekas see, kui formaalne oli intervjueeritavate keelekasutus, kui palju nad kaasasid huumorit, flirtisid vms. Kaks järgnevat intervjuu väljavõtet näitavad, kui erinev oli osalejate esialgne suhtlusmaneer.

Appi, ah et selline siis ongi intervjuu! Milline pinge! Mida öelda?! Ei tahaks öelda liiga palju! Aga ka mitte liiga vähe :-) Ehh, no see Tumblri asi on väga huvitav olnud, minu jaoks on see liikunud tavalise internetis aja surnuks löömise juurest ERAKORDSE aja surnuks löömise juurde, ja ma olen selle käigus saanud tuttavaks mõnede väga huvitavate inimestega ja neid paljalt näinud. (Simon, meili-intervjuu)

Kogemus on olnud elu muutev, erootiliselt värskendav. Tänu sellele on minus juurdunud veendumus, et minu "parim enne" aeg seksuaalselt ihaldusväärse naisena ei ole hoolimata sellest, et ma nii uskusin, 
sugugi möödas. Tumblr on võimaldanud mulle juurdepääsu teiste inimeste fantaasiatele ning õpetanud mulle palju inimseksuaalsuse ja iha keerukuse kohta. (Rachel, meili-intervjuu)

Sünkroonsete intervjuude kokkuleppimisel ja läbiviimisel püüdsin osalejatele pakkuda võimalikult palju vabadust selle osas, kui palju nad mulle oma Tumblr-välise elu kohta avaldada tahavad (k.a kas nad soovivad audio-video, audio või tekstipõhise chati intervjuud). Intervjuu järel viisin suhtluse tagasi platvormi sõnumirakendusse, tänasin uuesti intervjuu eest, palusin luba uitküsimusi esitada ning endale ükskõik millises selleks hetkeks loodud suhtluskanalis märku anda, kui intervjueeritavale meenub midagi asjakohasena näivat. Klassikalisest uurimisandmete usaldusväärsuse seisukohast võib selline lähenemine tekitada ebakindlust, ent kogukonna tavade kontekstis näis see mulle ainuvõimalikuna.

Õhustikuloome ja uurimissuhtluse seisukohast väidan, et kõik need mikrokommunikatiivsed sammud olid olulised, toimisid kumulatiivselt, ning et minu valmidus usaldada ilma tõendeid nõudmata aitas luua uurimisõhkkonda. Nüüd, mil olen enamikuga uuritavatest viinud läbi mitmeid intervjuusid (kuni viis intervjuud sama inimesega), neist mitmeid isiklikult kohanud, ning projekt on kasvanud oma esialgsetest plaanitud mõõtudest märksa suuremaks, võin öelda, et esimene intervjuu ise on parim õhustikuloome taktika, mida tuleks sellisena ka käsitleda. Ehkki paljud intervjueeritavad avaldasid juba enne esimest intervjuud mulle oma pärisnime, asukoha ja kontaktandmed, otsustasid teised selle kasuks alles paar päeva pärast intervjuud. Sageli esines seda, et uurimuses osalejad kirjutasid mulle hiljem, et lisada varem enda poolt öeldule detaile või midagi ausamalt "üles tunnistada" (vt allolev sõnumikatkend).

Üks asi tuli mul meelde ... see küsimus millele ma vastasin Kinsey
skaalaga ... see polnud vist päris õige vastus. Või noh ... ma panek-
sin ikka ennast skaalal 2-le, ma ei ole biseksuaalne, aga ... noh, ma
üritan öelda, et kuigi ma ütlesin, et mulle tüdrukud ei meeldi, siis
tegelikult meeldivad küll. Ja siis ma tahtsin veel öelda, et sa võid
mind kutsuda ...., see nimi mis ma sulle andsin, on mu Ameerika
nimi aga ... on mu päris nimi ja kõik mu sõbrad kutsuvad mind nii.

Arvestades, kui palju ma olen aastate jooksul oma intervjueeritavate juurde naasnud, et küsida täpsustusi või lisaintervjuusid, ning kui palju nad on saatnud mulle vihjeid, viiteid ja lisamaterjali, leian, et esmase intervjuu üks olulisemaid eesmärke ongi dialoogivõimaluse 
loomine. Isegi siis, kui uurimisprojekt ei ole esialgu plaanitud etnograafilisena ja ette on nähtud vaid üks intervjuu, soovitaksin intervjuu lõppu mitte käsitleda ega vormistada uurimissuhte lõpuna. Dünaamiline suhe on oluline ka uurimiseetika seisukohast, sest see võimaldab esialgu ettenägematuid küsimusi nende tekkides osalejatega arutada (internetiuurimuse eetika soovitusi vt Tiidenberg 2017a).

Hoolimata sellest, millised on erinevate uurijate hinnangud sellele, kuidas internetisuhtlus uurimissuhteid mõjutab, on kõik nõus, et suhte aluseks on teatav vastastikune usaldus. Eri autorite erinevad kogemused puudutavadki seda, kui lihtne või keeruline on neil olnud oma uurimisoludes usaldust tekitada ja tunda.

Nii soovitavad Mann ja Stewart (2000) vastastikust eneseavamist ja korduvat suhtlust. Nad rõhutavad, et veebiintervjuude puhul on oluline, et intervjueerija suudaks kasutada valitud suhtluskanalit aktiivseks kuulamiseks, julgustamiseks ja empaatia kuvamiseks (samas). Meili-intervjuusid läbi viinud Joelle Kivits (2005) väidab, et ka tema uurimuses oli määrava tähtsusega vastastikune intervjuueelne eneseavamine. Kivits (2005) nendib, et usalduslik suhe eeldab mõlema osapoole pikaajalist pühendumist ning selleks tarvilikud suhtlusoskused arenevad intervjueerimisprotsessi käigus, mis meili-intervjuude puhul võib kesta kuid ja vajab rohkelt kannatust. Ka Shani Orgad (2005) peab veebipõhise uurimisusalduse loomise puhul väga oluliseks suhtluse ajalist mõõdet. Tema leidis, et oma uuritavate küsimustele kiiresti vastates ja nende jaoks alati olemas olles näitas ta, et tema kui uurija on tõsiselt võetav ning uuritavate keerukate ja kohati südantlõhestavate lugude ${ }^{17}$ kuulamisele pühendunud. Orgadi $(2005,56)$ sõnul on hoolimine, tähelepanu ja siiras huvi informantide elatud kogemuste vastu (isegi kui need ei puuduta uurimisküsimust) peamine, millega saab innustada uuritavaid osalema.

\section{Usalduskogukond ja turvaala}

Usaldus muutus 1990. aastail sotsiaalteadustes populaarseks teemaks, kuna ühiskondlikud muutused tõid kaasa sotsiaalsete protsesside muutumise läbipaistmatuks, mistõttu inimesed seisid silmitsi nii laienenud valikuvõimaluste kui ka suurenenud ebakindlusega ja

${ }^{16}$ Orgad uuris vähihaigete veebifoorumeid. 
usaldus muutus hädavajalikuks (Sztompka 1999, 12-14). Seejuures käsitlesid sotsioloogid usaldust inimestevaheliste suhete tunnusena ja kultuurilise ressursina (samas). Umbes samal ajal kirjutas filosoof Philip Pettit $(1995,216)$ usalduse riuklikkusest (ingl the cunning of trust). Ta väitis, et kui me usaldame inimesi, ilma eelneva selge põhjuseta, võib see ajendada neid käituma ootuspäraselt, et usaldust õigustada. Sel juhul toimib usaldus hea tahte märgina, omamoodi kutsena usaldaja poolt oodatud viisil käituma.

Internetiuurijad on samuti usalduse küsimusega tegelenud, sealjuures nii Philip Pettiti (1995) kui ka Piotr Sztompka (1999) töödele toetudes. ${ }^{18}$ Samantha Henderson ja Michael Gildig (2004) väidavad veebisõpruste uurimuse põhjal, et online usaldusel on neli peamist allikat: (a) suhtluspartneri pseudonüümi või tema veebivälise identiteediga kaasnev maine; (b) see, kuidas inimene veebis teistega käitub; (c) eelpühendumine (ingl pre-commitment), mis tähendab et inimesed avavad end, et ka suhtluspartneris sama esile kutsuda; ning viimaks (d) ühiskondlikud suhteid ja suhtlust puudutavad faktorid, mis soosivad giddenslikku (1991) "puhast suhet". ${ }^{19}$ Eva Svedmark (2016) kirjutab oma doktoritöös, et usaldus on üks põhilisi "tehnoemotsioone". Tema sõnul ahendavad ja mõjutavad usaldust tehnoloogilised, digitaalsed ning materiaalsed elemendid. Usaldust võib niisiis tunda iseenese vastu, teiste inimeste vastu ning tehnoloogia vastu (Svedmark 2016).

Kui veebikogukond usub, et siiralt osalemise, isikliku info jagamise, emotsionaalse panustamise, suhestumise ja enesepaljastamisega ehk iseenese vabatahtlikult haavatavaks jätmisega ei kaasne ärakasutamist, toimib kogukond turvaalana. Turvaalad (ingl k safe spaces) on kohad, kus "järelvalve ja ärakasutamine" on minimaalne (Harris 2005, 41) ning inimesed saavad ohtu kartmata osaleda avameelses dialoogis ja seeläbi ühiskonnas valitsevate tähendussüsteemide muutmises (Harris 2005; Muise 2011). Paul de Laat (2008,

${ }^{17}$ Siinkohal tuleb välja tuua, et nii Sztompka (1999) kui ka Pettit (2004) on samuti kirjutanud interneti ja usalduse teemadel. Mõlemad leidsid, et internet ei ole anonüümsuse ja identiteedi varjamisvõimaluse tõttu usalduse loomiseks sobiv koht. Hinnates mõlema autori panust usaldusemõiste arendamisse, toetun internetipõhise usalduse kirjeldamisel siiski internetiuurimuse ekspertide empiirilistele uurimustele.

${ }^{19}$ Giddens kirjeldas hilismodernset sõprussuhet puhta suhtena (1991, 90). Puhas suhe põhineb intiimsusel, võrdsusel, sisekaemusel, vabatahtlikul pühendumusel ning vastastikusel usaldusel, see on suhe, milles ollakse suhte enese nimel. 
61) on sarnast tendentsi märganud isiklikes blogides, mis toimivad just eeldatava usalduse pinnalt. De Laati (2008) inspiratsiooniks on Pettiti (1995) juba mainitud idee, sellest, et inimesed osutuvad usaldusväärseks seetõttu, et neid usaldatakse, mitte seetõttu, et nad on loomupoolest usaldusväärsed ja head. De Laat (2008) nimetab seda vastastikuse imetluse ja usalduslikkuse taastootmise tsükliks.

Minu uuritavad teevad ennast seksikaid selfisid postitades kahetiselt haavatavaks. Esmalt sotsiaalsetele normidele, mis avalikku seksuaalsust ja alastust taunivad, ja teisalt oma ebatäiustega keha paljastamisega välimusekriitilises visuaalkultuuris. Seksikate selfide postitamist võib käsitleda ennatliku usalduse vormina, mis eeldab ja loob vaatajate poolset usaldusväärsust (Pettit 1995; de Laat 2008). Seda täheldab allolevas intervjuukatkes ka üks minu uuritavatest.

Üldiselt on nii et me ei ... siin kogukonnas ei ole kombeks öelda asju, mis võiks teise inimese enesekindlusele halvasti mõjuda, eriti selles, mis puudutab nende keha või ... jah, just peamiselt keha. Mulle tundub, et ühiskonnana oleme me väga, väga, väga kriitilised inimeste kehade ja välimuse osas. Ja seega siin kogukonnas on selline ... negatiivsete kommentaaride vältimine küll nagu vaikimisi reegel. Ja ma ei tea isegi täpselt, kuidas see toimib, või kuidas seda kirjeldada. Mina tajun seda "kohtle teisi nii nagu sa tahad, et sind koheldaks" filosoofiana. Et see on nagu meie kogukonna reegel. See peaks justnagu ka laiema ühiskonna reegel olema, aga enamasti ei ole. Seevastu siin Tumblris järgitakse seda päris karmilt. (Jenna, intervjuu 2011) ${ }^{20}$

See tähendab, et lisaks ühistele huvidele ja sarnasusele, mis veebipõhist suhtlust sageli suunab, ühendab minu uuritavaid tunne, et usaldus on just see valuuta, mis on nende kogukonnas omandanud kõige suurema sotsiaalse tähenduslikkuse. De Laati (2008) mainitud usalduslikkuse tsükkel toimib, kuna inimestel on kogemus, et nende blogi külastajad suhtuvad nende alastusse soosivalt, mõistvalt, või kui mitte, siis pöörduvad ilma solvamata ja kiusamata eemale. Lisaks toodavad seksikad selfid selles kogukonnas usaldusväärsust ka teisel moel. Nad toimivad tõendusena, et blogi pidav inimene on tõepoolest see, kellena end esitleb, leevendades eelpool mainitud autentsuse ja anonüümsuse dialektilisi pingeid, mida paljud uurijad peavad kogu internetisuhtluse lahendamata probleemiks.

${ }^{20}$ Intervjuukatked sellises tõlkes on toodud ära ka Tiidenberg 2017b. 
See on nagu mingi usalduse küsimus ... kui sa endast pilte postitad, siis sa oled palju usutavam ja teistel on lihtsam sind usaldada. Sest kui sa paned endast alasti pildi, siis on vähetõenäoline, et sa teise inimese alasti pildi kohta halvasti ütled või seda näiteks kuhugi lekitada üritad. Piltide postitamine on nagu meie viis öelda "näed, see olen tõesti mina, selline nagu ma olen”. (Marilyn, grupiintervjuu 2012)

See, et alastipildid toodavad ja taastoodavad usaldust, näib esmapilgul ebaratsionaalne. Plaanimatu alastusega kaasneb tavaliselt häbistamine (vt nt kuulsuste selfiskandaale ${ }^{21}$ või kättemaksuporno mõiste alla koonduvat). Sellises kontekstis määratlematule publikule seksikaid selfisid postitada tundub ebamõistlik. Kuid just selles seisneb Pettiti $(1995,216)$ sõnul usalduse riukalikkus - me usaldame inimesi ilma, et nad meile selleks põhjust andnud oleks, ja see ajendab neid usaldusväärselt käituma. Kui selline NSFW blogimisega kaasnev vabatahtlik haavatavus eeldab, võimaldab ja tõestab osalejate usaldusväärsust, saab usaldusest ja usaldusväärsusest sellele kogukonnale iseloomulikuna tajutav tunnus, mis omakorda tähendab, et kogukond muutub oma liikmetele turvaalaks (Harris 2005; Muise 2011). Sellest, et osalised tajuvad kogukonda turvaalana, saab aga omakorda usaldust (taas)tootev mehhanism. Vabatahtlikku haavatavust ja usaldust soosivad seega nii inimeste korduvad, isiklikud ja teiste jälgimisel põhinevad positiivsed kogemused kui ka see, et keskkonda ja kogukonda tervikuna tajutakse turvaalana, kus tolerantsus on norm.

\section{Lõpetuseks}

Kvalitatiivne uurimus on minu meelest mitmes olulises mõttes nagu inimsuhted üldiselt: nii veebipõhisena kui ka veebivälisena keeruline ja nüansirikas ning pidevat dialektiliste pingete lahtiseletamist eeldav (Baym 2009). Siinkohal tundub kasulik Sarah Tracy (2013) nõuanne läheneda uurimusele lähtekohati, ${ }^{22}$ ehk teha uurimussuhteid puudutavaid otsuseid toetudes sellele, milline on uurija lähtekoht, milliseid uurimisteemasid ja andmekogumist

${ }^{21} \mathrm{Nt}$ Jennifer Lawrence või Leslie Jones, kelle iCloud fotosalvedesse sisse murti ning sealt leitud seksikaid selfisid ja muid pilte internetis levitati.

${ }^{22}$ Meetodikirjandus pakub palju erinevaid lähtekohti, nt etnograafias tuntud skaala täisosalejast täisvaatlejani; Tracy (2013) lisatud mänglev osaleja (ingl play participant), Flicki (1998) pakutud võõra, külalise, kaasatu ja siseringi kuuluja positsioonid jms. 
see võimaldab ning milline oleks sobivaim uurijaperspektiiv (ingl standpoint of participation) konkreetsele uurimisküsimusele vastamiseks. Tracy (2013) toob erinevate uurijaperspektiivide näiteks interaktiivse intervjueerimise, feministliku sõprusintervjueerimise ning dünaamilise intervjueerimise, mis kõik on dialoogilised ja intensiivselt suhtluslikud uurijaperspektiivid. Samas nendivad Sharlene Nagy Hesse-Bieber ja Patricia Leavy (2011), et ka kõrvalseisja positsioon võib teatud gruppidega suheldes anda eelise, kuna võõraga on lihtsam rääkida ja võõras võib küsida nähtuste kohta, mis tunduvad antud kultuuris ilmselged ja iseenesestmõistetavad.

Mulle näib, et ka siis, kui uurimisküsimusele vastamiseks ei ole võimalik või sobiv läheneda osalejana, tuleb teatav osaleja lähtekoht kasuks igale kvalitatiivsele andmeloome protsessile. Kui uurija läheneb pigem osalejana, võib eeldada, et suhete areng uuritavatega toimub niisamuti nagu ülejäänud kogukonnaliikmete vahel - pühendumise, osalemise ja vastastikuse eneseavamise kaudu usalduslikkust taastootvaid käitumistavasid järgides. Kui valida pigem vaatlev positsioon, tuleb mõelda, kuidas usalduse protsesse imiteerida. Sellele saab kaasa aidata, kasutades uurimuse teemal suhtlemiseks sarnast suhtlusstiili, mida kasutavad omavahel kogukonna liikmed. ${ }^{23}$ Seda tegin ka mina, kui jagasin juba esimese intervjuuni viiva suhtluse paljudeks mikrokontaktideks. Selline liigendatus ning formaalse ja mitteformaalse läbipõimimine soosis kindlasti isiklike teemade arutamist intervjuus, kuid usun, et see vähendas ka näiteks ärajäetavate intervjuude osakaalu. Osalejail oli lihtsam minult ajamuutust paluda, seevastu kui formaalsema ja vähematest suhtlussammudest koosneva suhte puhul oleksid mitmed uuritavad oma sõnul kehva meeleolu või kiire perioodi tõttu intervjuu pigem ära jätnud.

Teine viis kogukonna suhtlusdünaamikat imiteerida on uuritavatega samade suhtluskanalite kasutamine uurimuse teemal vestlemiseks. Näiteks võib luua uuritavate kasutatud platvormile uurijablogi. See võimaldab osalejail mugavalt ja lihtsa vaevaga uurija oma igapäevastesse sisuvoogudesse kaasata ja seeläbi tema tegemistega kursis olla. Sel juhul peaks uurija olema võimeline ja valmis looma kogukonna ja platvormi reeglite kohase sageduse ja stiiliga sisu. Mina alustasin oma uurimisblogi umbes samal ajal

${ }^{23}$ Selleks, et teada, millised kanalid ja stiil see on, on muidugi vajalik esmane kultuuriga tutvumise etapp, kus uurija vaatlus on vähemalt mingil määral osalev. 
kui viisin läbi ja leppisin kokku esimesi intervjuusid. See oli algselt mõeldud vaid uurimuses osalejatele ja privaatne, hiljem nende nõusolekul avatud (et saaksin kirjutatut ka kolleegidega jagada). Blogipidamine toimis uurijamärkmikuna (Halavais 2006), kus sain plaane pidada, keerulistest momentidest kirjutada, mõtiskleda, teha teatud väljavõtteid ning tegelda andmete esialgse kategoriseerimise või analüüsiga. Samas aitas uurijablogi kaasata uuritavaid pikaldasse uurimisprotsessi ning tõsta minu ja minu uurimuse usaldusväärsust, kinnitades osalejatele, et ma olen, kes väidan end olevat, ja püüan endale usaldatud infoga teha enamvähem seda, mida lubasin. Uurimuse käigus juhtus sageli, et sain uuritavatelt mõni päev või nädal pärast postituse tegemist kirja või sõnumi, mida käsitlesin muuhulgas "osaleja kontrollina"24 (ingl member check) (vt allolev katkend):

Ma saan aru, et sa ei taha intervjueeritavaid oma seisukohtadega intervjuu ajal mõjutada. Minuga läks sul see kindlasti korda. Aga ma hakkasin mõtlema, äkki sa tahad tulevikus teha dialoogi või mitme inimese vestluse vormis intervjuu, kus sa esitad nimelt oma katsejäneste (ja ma ütlen seda armastusega, mul on hea meel üks neist olla) vaateile väljakutseid? Mina tahaks küll teada, mida sina neist asjadest arvad.

Kokkuvõtvalt soovitan igal võrgutehnoloogiatest vahendatud kvalitatiivset uurimust plaanival uurijal mõelda vähemalt alljärgnevale.

- Millised on uurija enda suhtluskompetentsid, suhtlusstiil ja suhtlemise eelistused?

- Millel põhineb uurijat huvitava kogukonna, grupi või kultuuri kuulumistunne? Kas uurija aktsepteerib neid kultuurinorme ja käitumistavasid?

- Millised on uurija konkreetse uurimissituatsiooni tehnilised lubavused ja kitsaskohad, mis usalduse tekkes ja loomises rolli mängivad?

Neile küsimustele saab vastata vaid iga uurija individuaalselt. Etteantavaid ja mehhaaniliselt järgitavaid reegleid siin ei ole. Samas usun, et läbimõeldult tegutsedes ja läbivalt paindlikku meelt säilitades on ka veebipõhistes uurimissituatsioonides võimalik luua

${ }^{24}$ Osaleja kontroll (mõnikord ka informandi tagasiside või respondendi poolne kinnitus) on kvalitatiivses uurimuses kasutatav tehnika, kus uuritavatelt küsitakse tagasisidet uurija teatud tõlgendustele, et suurendada uurimuse usaldusväärsust. 
intensiivseid ja rõõmu toovaid suhteid, mis aitavad rikkalikult ja huvitavalt vastata nüansirikastele uurimisküsimustele.

\section{Kirjandus}

Archer, Richard L. 1979 Role of personality and the social situation. - Chelune, Gordon J. Self Disclosure: Origins, patterns, and implications of openness in interpersonal relationships. The Jossey-Bass social and behavioral science series. San Francisco: Jossey Bass, 28-58.

Bakardjieva, Maria 2009. A response to Shani Orgad. - Markham, Annette N. \& Nancy K. Baym, Nancy K. (toim). Internet Inquiry: Conversations about Method. Thousand Oaks: Sage, 54-60 (doi: 10.4135/9781483329086.n5).

Baym, Nancy K. 2000. Tune In, Log On: Soaps, Fandom, and Online Community. New Media Cultures. Thousand Oaks: Sage.

Baym, Nancy K. 2009. What constitutes quality in qualitative internet research? - Markham, Annette N. \& Baym, Nancy K. (toim). Internet Inquiry: Conversations about Method. Thousand Oaks: Sage, 173-189 (doi: 9781483329086.n16).

Baym, Nancy K. 2015. Personal Connections in the Digital Age. Digital Media and Society. Wiley. Kindle Edition.

Boellstorff, Tom \& Nardi, Bonnie \& Pearce, Celia \& Taylor, T. L. 2012. Ethnography and Virtual Worlds. A Handbook of Method. Princeton University Press.

boyd, danah 2010. Social Network Sites as Networked Publics: Affordances, Dynamics, and Implications. - Papacharissi, Zizi (toim). Networked Self: Identity, Community, and Culture on Social Network Sites. New York: Routlege, 39-58 (https://www.danah.org/papers/2010/ SNSasNetworkedPublics.pdf - 05.03.2018).

Cover, Rob 2012. Performing and undoing identity online: social networking, identity theories and the incompatibility of online profiles and friendship regimes. - Convergence. The International Journal of Research into New Media Technologies 18 (2), 177-93 (doi: 10.1177/1354856511433684).

de Laat, Paul B 2008. Online diaries: reflections on trust, privacy, and exhibitionism. - Ethics and Information Technology 10 (1), 57-69 (doi: 10.1007/s10676-008-9155-9).

Ellison, Nicole B \& Heino, Rebecca \& Gibbs, Jennifer 2006. Managing Impressions Online: Self-Presentation Processes in the Online Dating Environment. - Journal of Computer-Mediated Communication 11 (2), article 2 (doi: 10.1111/j.1083-6101.2006.00020.x).

Flick, Uwe 1998. An Introduction to Qualitative Research. Cambridge: Cambridge University Press.

Flick, Uwe (toim) 2017. The SAGE Handbook of Qualitative Data collection. Los Angeles: SAGE.

Usaldus internetis - juurdepääs ja suhted uuritavatega 
Gajjala, Radhika 2009. A response to Shani Orgad. - Markham, Annette N. \& Baym, Nancy K. (toim). Internet Inquiry: Conversations about Method. Thousand Oaks: Sage, 61-67 (doi: 10.4135/9781483329086. n6).

Gibson, James 1977. The theory of affordances. - Shaw, Robert \& Bransford, John (toim). Perceiving, acting, and knowing: Toward an ecological psychology. Hillsdale: Lawrence Erlbaum Associates, 67-82.

Giddens, Anthony 1991. Modernity and the Self: Self and Society in the Late Modern Age. Stanford, CA: Stanford University Press.

Gobo, Giampetro 2008. Doing Ethnography. Los Angeles: SAGE.

Goffman, Erving 1956. The Presentation of Self in Everyday Life. Garden City: Doubleday.

Guimarães, Mario, J. L. Jr 2005. Doing anthropology in cyberspace: fieldwork boundaries and social environments. - Hine, Christine (toim). Virtual methods: Issues in social research on the internet. Oxford, Berg, 141-156.

Halavais, Alex 2006. Scholarly blogging: Moving toward the visible college. Bruns, Axel \& Jacobs, Joanne (toim). Uses of blogs. New York: Peter Lang Publishing, 117-126.

Hall, Jeffrey A. \& Pennington, Natalie 2012. What you can really know about someone from their Facebook profile (and where you should look to find out). - Cunningham, Carolyn (toim). Social Networking and Impression Management. Self-Presentation in the Digital Age. Lanham, MD: Lexington Books, 247-270.

Harris, Anita 2005. Discourses of desire as governmentality: Young women, sexuality and the significance of safe spaces. - Feminism \& Psychology 15, 39-43 (doi: 10.1177/0959353505049702).

Henderson, Samantha \& Gilding, Michael 2004. "I've never clicked this much with anyone in my life": trust and hyperpersonal communication in online friendships. - New Media \& Society 6 (4), 487-506 (doi: 10.1177/146144804044331).

Hesse-Bieber, Sharlene Nagy \& Leavy, Patricia 2011. The Practice of Qualitative Research. Los Angeles: SAGE. Chicago

Joinson, Adam N. 2005. Internet Behaviour and the design of virtual methods. - Hine, Christine (toim). Virtual Methods: issues in social research on the Internet. Oxford: Berg, 21-34.

James, Nalita \& Busher, Hugh 2009. Online Interviewing. London, UK: Sage.

James, Nalita \& Busher, Hugh 2016. Online interviewing. - Qualitative Research. Los Angeles: SAGE (doi: 10.4135/9780857024503).

Kendall, Lori 2009. Question four: How do issues of Gender and Sexuality influence the structures and processes of qualitative internet research? - Markham, Annette N, \& Baym, Nancy K. (toim). Internet Inquiry. Conversations about method. Los Angeles: SAGE Publications, 99-119. 
Kiesler, Sara \& Siegel, Jane \& McGuire, Timothy 1984. Social psychological aspects of computer-mediated communications. - American Psychologist 39 (10), 1123-1134 (doi: 10.1037/0003-066X.39.10.1123).

Kivits, Joelle 2005. Online interviewing and the research relationship. Hine, Christine (toim). Virtual methods: Issues in Social Research on the Internet. Oxford, UK: Berg, 35-50.

Mann, Chris \& Stewart, Fiona 2000. Internet communication and qualitative research: A handbook for researching online. London: Sage.

Markham, Annette N. 2004. Internet Communication as a Tool for Qualitative Research. - Silverman, David (toim). Qualitative Research: Theory, Method, and Practices, 2nd Edition. London: Sage

Markham, Annette N. 2005. The methods, politics, and ethics of representation in online ethnography. - Denzin, Norman \& Lincoln, Yvonna (toim). The Sage Handbook of Qualitative Research, 3rd Edition. Thousand Oaks: Sage, 793-820.

Markham, Annette N. 2006. Method as ethic, ethic as method. - Journal of Information Ethics 15 (2), 37-55.

Morrison, Aimee 2014. Facebook and Coaxed Affordances. - Poletti, Anna \& Rak, Julie (toim). Identity Technologies: Constructing the Self Online, University of Wisconsin Press. Kindle Edition.

Muise, Amy 2011. Women's sex blogs: challenging dominant discourses of heterosexual desire. - Feminism \& Psychology 21 (3), 411-419.

Norman, Donald A [1988] 1990. The design of everyday things. New York: Doubleday.

Orgad, Shani 2005. From online to offline and back: moving from online to offline relationships with research informants. - Hine, Christine (toim). Virtual Methods: issues in social research on the Internet. Oxford: Berg, 51-66.

Orgad, Shani 2009. Question Two: How Can Researchers Make Sense of The Issues Involved in Collecting and Interpreting Online and Offline Data? - Markham, Annette N. \& Baym, Nancy K. (toim). Internet Inquiry, conversations about method. Thousand Oaks: Sage, 3-52.

Pettit, Phillip 1995. The cunning of trust. - Philosophy and Public Affairs 24 (3), 202-225 (doi: 10.1111/j.1088-4963.1995.tb00029.x).

Pettit, Phillip 2004. Trust, Reliance and the Internet - Analyse \& Kritik 26, 108-121 (doi: 10.1515/auk-2004-0106).

Ray, Audacia 2007. Naked on the Internet. Hookups, Downloads and Cashing in on Internet Sexploration. Emeryville, CA: Seal Press.

Sanders, Teela 2005. "Researching the Online Sex Work Community." Hine, Christine (toim). Virtual Methods: issues in social research on the Internet. Oxford: Berg, 67-80.

Smith, Sidonie \& Watson, Julia 2014. Reading Autobiography: A Guide for Interpreting Life Narratives. - Poletti, Anna \& Rak, Julie (toim). Identity Technologies: Constructing the Self Online. University of Wisconsin Press. Kindle Edition. 
Sproull, Lee \& Kiesler, Sara, B 1991. Connections: New ways of working in the networked organization. Cambridge, MA: MIT Press.

Statista 2018. Most popular social networks worldwide as of April 2018, ranked by number of active users (in millions). https://www.statista.com/ statistics/272014/global-social-networks-ranked-by-number-of-users/.

Sztompka, Piotr 1999. Trust: A Sociological Theory. Cambridge: Cambridge University Press.

Suler, John 2004. The Online Disinhibition Effect. - Cyberpsychology \& Behavior 7, 3 (doi: 10.1089/1094931041291295).

Svedmark, Eva 2016. Becoming Together and Apart. Technoemotions and other posthuman entanglements. Akademisk avhandling. Väitekiri. Institution för Informatik Genusforskarskola, Umeå Center för Genusstudier Umeå universitet, Umeå 2016.

Tiidenberg, Katrin 2017a. Ethics in Digital Research. - Flick, Uwe (toim). The SAGE Handbook of Qualitative Data Collection. Los Angeles: Sage (doi: 10.4135/9781526416070.n30).

Tiidenberg, Katrin 2017b. Ihu ja hingega internetis, kuidas mõista sotsiaalmeediat. Acta Socialia. Elustiilide uurimused. Tallinn: Tallinna Ülikooli Kirjastus.

Tracy, Sarah J. 2013. Qualitative research methods: Collecting evidence, crafting analysis, communicating impact. Hoboken, NJ: Wiley-Blackwell.

\section{Summary}

\section{Trust in the Internet - access and research relationships}

Keywords: access to the field, digital research, internet research, research relationships, trust

This chapter discusses issues of access, rapport and trust in qualitative internet research. Thick descriptions and their context sensitive interpretations need a basic level of trust between the researcher and the participant, yet networked communication, and specific social media platforms, have certain socio-technical affordances that shape and constrain how we interact and build trust. Limited visual and social cues and the possibility of anonymous or pseudonymous interaction do not preclude trusting research relationships, but need to be taken into account. To explore how methods and technology intersect in issues of access and trust, this chapter relies on the author's ethnographic research with a community of NSFW selfie enthusiasts on Tumblr. I describe how I incorporated Tumblr's platform affordances and my studied group's communicative norms into my strategy of gaining access and building research relationships. I then analyze how trust functions within this NSFW selfie community. As a result I offer a set of questions answering of which I believe would help researchers understand and build trust in networked research situations. 


\section{PILDI SISSE MINEK. Artikleid välitööde alalt}

\section{Koostanud ja toimetanud EDA KALMRE}

http://www.folklore.ee/rl/pubte/ee/cf/pildisisse

ISBN 978-9949-586-93-6

DOI $10.7592 / \mathrm{TF} 11$

Tartu 2019

Trükis ilmunud:

Pildi sisse minek. Artikleid välitööde alalt.

Tänapäeva folkloorist 11. Tartu 2019

Sarja peatoimetaja: Eda Kalmre

Kogumiku koostaja ja toimetaja: Eda Kalmre

Keeletoimetaja: Asta Niinemets

Kaanekujundus: Artur Kuus

Küljendus: Diana Kahre

Veebiväljaanne: Diana Kahre

Trükitud Eesti Kultuurkapitali toetusel. Väljaande valmimine on seotud Euroopa Liidu Euroopa Regionaalarengu Fondi (Eesti-uuringute Tippkeskus) ja Eesti Haridus- ja Teadusministeeriumi uurimisprojektiga IUT 22-5. Väljaande valmimist on toetanud Akadeemiline Rahvaluule Selts.

E-raamatu valmimist toetas: EKKM14-344 Eesti keele, kultuuri ja folkloori kasutusalade laiendamine ja tutvustamine elektroonilistel infokandjatel.

(C) Eesti Kirjandusmuuseum 2019

(C) Eda Kalmre ja autorid

(C) Artur Kuus 